Paedagogia Christiana

I/27 (20I I) - ISSN 1505-6872

Bogustaw Śliwerski*

Łódź

\title{
Badania socjopedeutologiczne ks. Jana Zowczaka w kontekście kolejnych prac nad kodeksem etycznym nauczycieli
}

Debata na temat dialogu w szkole nie powinna pomijać kwestii etyki zawodowej nauczycieli. Istotne są w tym zakresie zarówno projekty kodeksów dla tej profesji, jak i wyniki badań empirycznych, wskazujące na kondycję społeczno-moralną nauczycieli w polskich szkołach. W 2009 roku ukazała się jedna z najciekawszych, syntetycznych rozpraw monograficznych temu poświęconych, autorstwa ks. Jana Zowczaka - pt. Etos nauczycieli $w$ warunkach polskiej transformacji ${ }^{1}$. Jej pojawienie się na polskim rynku wydawniczym poprzedziło szereg artykułów naukowych w czasopismach i rozprawach zwartych, poświęconych między innymi problematyce tożsamości zawodowej nauczycieli, których treść sytuuje się na pograniczu socjologii z pedagogiką ogólną, pedeutologią i pedagogiką porównawczą. Ks. Jan Zowczak jest pracownikiem Instytutu Socjologii Uniwersytetu Kardynała Stefana Wyszyńskiego w Warszawie, byłym dyrektorem Katolickiego Liceum Ogólnokształcącego w Siedlcach oraz założycielem i prezesem Fundacji Bonum Educationis. Jest też członkiem Polskiego Towarzystwa Socjologicznego i Sekcji Wykładowców Katolickiej Nauki Społecznej przy Komisji Episkopatu Polski ds. Nauki i Wiary.

* Prof. dr hab. Bogusław Śliwerski - autor jest profesorem zwyczajnym Chrześcijańskiej Akademii Teologicznej w Warszawie; wiceprzewodniczącym Komitetu Nauk Pedagogicznych PAN, wiceprzewodniczącym Polskiego Towarzystwa Pedagogicznego.

${ }^{1}$ J. Zowczak, Etos nauczycieli w warunkach polskiej transformacji. Studium socjologiczne, Warszawa 2009. 
Mamy tu rozprawy o charakterze teoretycznym, historyczno-problemowym i normatywnym, które są ważkie dla współczesnych badań nad zawodem nauczyciela. Ich autor nie podejmuje kwestii, które nie byłyby związane z jego kompetencjami metodologicznymi, gdyż przywołując wątki historyczne, czyni je przedmiotem interesującego zarysowania dynamiki przemian w funkcjonowaniu roli nauczycielskiej w różnych epokach i kulturach $^{2}$ po to, aby na tym tle zrekonstruować adresowane do przedstawicieli tej profesji potrzeby i postulaty społeczne. Ich autor ciekawie wykazuje zachodzące w tej mierze przeobrażenia, by zarazem upomnieć się o uwzględnienie w diagnozie owej profesji realiów doby transformacji, a także pojawienia się w polskim szkolnictwie - po długich latach nieobecności - nauczycieli religii ${ }^{3}$. Sa to o tyle istotne teksty, że pokazują - bez politycznego czy ideologicznego interesu władzy - edukacyjne argumenty na rzecz przywrócenia tej dziedziny wychowania, która jest konieczna do jego humanistycznego i integralnego dopełnienia. W duchu jedności nauk humanistycznych ks. J. Zowczak wzbogaca współczesną debatę na temat roli ewangelizacji w toku szkolnej edukacji.

Wyniki poprzedzających jego najnowsze badania diagnoz socjologicznych obejmują tak interesujące i najważniejsze wymiary nauczycielskiego zawodu, jak kwestie: uznawanych przez nauczycieli wartości ${ }^{4}$, postrzegania przez nich sfer możliwej współpracy szkoły z rodzicami ${ }^{5}$, postaw polskich nauczycieli wobec religii, ich świadomości religijnej i zachowań religijnych $^{6}$, czynników decydujących o wyborze tego zawodu ${ }^{7}$, poczucia tożsa-

2 Tenże, Dynamika zawodu nauczyciela a obecność katechety $w$ szkole, „Kwartalnik Pasterski Diecezji Siedleckiej" 1/3 (2005), s. 79-89.

3 Tamże; tenże, Kompetentny wychowawca w trzecim tysiacleciu, w: A. Kryński (red.), Ewangelizacja a edukacja w trzecim tysiacleciu, Częstochowa 2002, s. 125-130.

${ }^{4}$ Tenże, Wartości osobowe i społeczne nauczycieli, „Saeculum Christianum” 1/12 (2005), s. 175-198.

${ }_{5}^{5}$ Tenże, Wpływ rodziców na funkcjonowanie szkoły, „Teologiczne Studia Siedleckie” 1 (2005), s. 10-21.

${ }^{6}$ Tenże, Religijność polskich nauczycieli, „Teologiczne Studia Siedleckie” 1 (2005), s. 26-37; tenże, Postawy nauczycieli wobec religii, w: U. Bejma (red.), Społeczeństwo polskie w procesie zmian, Warszawa 2008, s. 239-259.

${ }^{7}$ Tenże, Wybór zawodu nauczyciela w warunkach polskiej transformacji, „Wiadomości Diecezjalne Siedleckie" 1 (2008), s. 187-204; tenże, Wybór zawodu nauczyciela a zasady katolickiego wychowania, „Kwartalnik Pasterski Diecezji Siedleckiej” 2 (2006), s. 75-87; tenże, Motywy wyboru zawodu nauczycielskiego w warunkach polskiej transformacji-perspektywa socjologiczna, w: K. Chałas (red.), Kreowanie tożsamości szkoły, t. 2: Konteksty historyczne, społeczno-kulturowe, edukacyjne, Lublin 2009, s. 239-249. 
mości zawodowej nauczycieli ${ }^{8}$, postaw nauczycieli wobec uczniów ${ }^{9}$, opinii nauczycieli o szkole, jej zadaniach i reformach ${ }^{10}$. Przywołane tu rozprawy znakomicie wpisują się w diagnozę kondycji nauczycielstwa polskiego okresu transformacji ustrojowej po 1989 roku oraz wskazują na te problemy, które mogą i powinny być przedmiotem dalszych badań naukowych. Wiele wniosków z tych diagnoz, kumulując się z wynikami badań pedeutologów, powinno być przedmiotem pogłębionej refleksji polityków oświatowych, by w toku planowanych reform czy zmian edukacyjnych można było uwzględnić te obszary funkcjonowania zawodu nauczycielskiego, które wymagają istotnych, a popartych konkretnymi rozwiązaniami napraw czy troski.

Autor w pewnej mierze nawiązuje do przesłanek wcześniejszych badań Marcina Drewicza, którego także interesował etos nauczycieli czteroletnich liceów ogólnokształcących (okres sprzed reformy ustrojowej M. Handke), ze względu na rozbieżność z jego źródłem, jakim są zasady katolickiego wychowania $^{11}$. Dostrzega się zresztą wyraźne podobieństwo w określaniu istoty etosu nauczycielskiego zawodu u obu tych socjologów. Diagnoza M. Drewicza dotyczy jednak postaw nauczycieli z 1997 r., a więc z początkowego okresu transformacji III RP, obejmując pedagogów z trzech regionów naszego kraju (Małopolska Południowa, Warszawa, Warmia, Mazury i Suwalszczyzna), jakie zostały wyłonione w wyniku dającego się wówczas rozpoznać poparcia ich mieszkańców dla określonych stronnictw politycznych. Jak wykazały badania M. Drewicza, zgodność pomiędzy wartościami katolickimi i odpowiadającym im zachowaniem miała miejsce w nielicznej, bo mniejszościowej dla tego środowiska zawodowego grupie zwolenników opcji katolicko-patriotycznej (ok. 1/4 badanych). Jak się okazało, przeważają wśród powyższych nauczycieli zwolennicy etosu liberalno-lewicowego, a więc odbiegającego od społecznego nauczania Kościoła.

Rozprawy ks. J. Zowczaka mają nieco szerszy charakter diagnostyczny, będąc nie tylko socjologiczną diagnozą stanu nauczycielstwa polskiego, ale i weryfikacją socjologiczną normatywnych przesłań adresowanych do tej profesji z różnych stron i dziedzin życia społecznego. Analizy i uzyskane

${ }^{8}$ Tenże, Identyfikacja nauczycieli ze swoim zawodem $w$ warunkach polskiej transformacji, „Saeculum Christianum” 15 (2008), nr 2, s. 143-164; tenże, Główne grzechy polskiego nauczyciela, „Wiadomości Diecezjalne Siedleckie” 1 (2009), s. 49-59.

9 Tenże, Nauczyciel wobec ucznia w warunkach polskiej reformy edukacji, „Wiadomości Diecezjalne Siedleckie" (2008) - w druku; tenże, Portret polskiego nauczyciela - ocenianie, „Wiadomości Diecezjalne Siedleckie” (2008) - w druku.

${ }_{10}$ Tenże, Opinie nauczycieli o wybranych funkcjach systemu szkolnego, „Uniwersyteckie Czasopismo Socjologiczne" 3 (2009), s. 35-54; tenże, Duch reformy systemu edukacji $w$ Polsce a opinie nauczycieli na temat potrzeby zmian, $2009-\mathrm{w}$ druku.

${ }^{11}$ M. Drewicz, Etos nauczyciela liceum ogólnokształcacego we wspótczesnej Polsce a zasady katolickiego wychowania, Warszawa 2003. 
dane empiryczne trafnie autor ten porównuje $\mathrm{z}$ wynikami innych badań na dany temat. Swoimi diagnozami i opublikowanymi przez siebie raportami towarzyszy zachodzącym w kraju przemianom oświatowym, systemowym, włączając się zarazem w dyskurs publiczny na temat tego, w jakiej mierze każda $\mathrm{z}$ ekip rządzących $\mathrm{w}$ resorcie edukacji będzie musiała zmierzyć się z inhibitorami zmian edukacyjnych, wśród których jednym z nich są sami nauczyciele.

Nie da się bowiem doskonalić procesu kształcenia i wychowania w polskich szkołach, ani też wdrażać kolejnych reform strukturalnych czy programowo-metodycznych, jeśli ich realizatorami mają być nauczyciele, którzy (w świetle wyników badań):

- w $44 \%$ są w tym zawodzie z zamiłowania,

- w 19,3\% znaleźli się w tym zawodzie z przypadku,

- w 48,9\% określają swój stosunek do wiary jako wierzący i regularnie praktykujący, ale większość spośród wszystkich należących do związków zawodowych $(33,3 \%)$ należy do lewicowego Związku Nauczycielstwa Polskiego,

- nie są zainteresowani włączaniem rodziców w jakość procesów wychowawczych i kształcących w szkole, oponując przeciwko ich partycypowaniu w obsadzie nauczycieli, ocenie ich pracy, stosowanych przez nich metod wychowawczych, wyborze przedmiotów nauczania i programów oraz przekazywaniu wartości moralnych,

- w 45,3\% preferują życie w pokoju, w 18,5\% godność osoby ludzkiej, a tylko w $8,6 \%$ wolność, co potwierdza tezę czeskiego profesora pedagogiki Jana Průchy, że zawodu tego podejmują się osoby o słabym charakterze, posłuszne, mało krytyczne i pełne kompleksów,

- powinni realizować zadania wspomagające wyrównywanie szans edukacyjnych dzieci, ale takie wartości podstawowe, jak zabezpieczenie społeczne, równość społeczna i solidarność ludzi, uzyskały u nich - w przeprowadzonych badaniach - najmniej wyborów, bo w kolejności: $0,9 \%, 1,8 \%$ i $1,2 \%$,

- w 31,5\% opowiadają się za konsekwencją w stosowaniu ustalonych kryteriów wymagań, w $31,2 \%$ za obiektywizmem a w 44,1\% za okazywaniem uczniom szacunku bez względu na okoliczności jako cenione elementy etyki zawodowej,

- w przedziale $8-12 \%$ nie widzą powodu do dezaprobaty tak negatywnych zachowań nauczycieli wobec uczniów, jak stosowanie wobec nich wyzwisk, drwienie z nich, ośmieszanie ich, stosowanie wobec nich kar cielesnych (tu najwyższy wskaźnik dotyczy nauczycieli o poziomie średnio religijnym - 15,4\%), szantażu czy wywieraniu presji psychicznej, 
- w 41,5\% przyznają, że nauczyciel stawiający rząd ocen niedostatecznych w dzienniku lekcyjnym przy nazwiskach większości uczniów niewiele wymaga od siebie, a zbyt dużo od uczniów, zaś ok. 10\% spośród nich jest podatnych na manipulację w wystawianiu uczniom nieadekwatnych do ich rzeczywistych kompetencji ocen,

- w 53,6\% uważają, że obecne szkolnictwo funkcjonuje gorzej niż przed wprowadzeniem reformy, a przy tym nie dostrzegają w tym swojego udziału,

- w 88\% obciążają winą za kryzys w wychowaniu rodzinę, a w 23,9\% szkołę, zaś w 16,8\% nauczycieli, co także potwierdza opisywany przed laty przez J. Kozieleckiego w stosunku do tego stanu zawodowego syndrom N-1, czyli ,wszyscy są winni”, tylko nie ja,

- w 59,7\% mają satysfakcję z wykonywanej pracy,

- w 58,3\% interpretuja powody negatywnej identyfikacji z zawodem przede wszystkim niskimi zarobkami,

- w 31,8\% przyznają się do sporadycznego spóźniania się na lekcje,

- w 40,4\% są nadmiernie wrażliwi na krytykę, a w 23,7\% są bezkrytyczni wobec niedomogów własnej pracy.

Tak bolesną, a przecież prawdziwą, dobrze uzasadnioną naukowo ocenę stanu polskiego nauczycielstwa warto skonfrontować z obszernym studium tego autora na temat etosu nauczycieli w warunkach polskiej transformacji. Poświęcona jemu rozprawa budzi największe uznanie i to w kilku wymiarach. Jest to niewatpliwie nowatorskie merytorycznie i syntetyczne studium porównawcze wiedzy na temat nauczycielskiego etosu, którym tak łatwo szafuje się w debatach publicznych, czy w uzasadnieniach wdrażania przez władze kolejnych reform lub zmian edukacyjnych bez uświadamiania sobie tego, co się tak naprawdę za nim kryje i jaki jest jego rzeczywisty stan oraz jego uwarunkowania. Znakomita jest w tej pracy analiza podstawowej zmiennej, jaka jest etos i związane z nią wymiary odpowiedzialności zawodowej w perspektywie współczesnej wiedzy (nie tylko z socjologii, ale historii, aksjologii, prakseologii, prawa czy pedagogiki, w tym pedeutologii).

Przyjęte przez tego naukowca założenia metodologiczne własnych badań, w tym troska o ich reprezentatywność, stanowią wzór dla pedagogów, wśród których - co muszę z goryczą stwierdzić - nawet profesorowie pedeutologii weryfikują swoje hipotezy na próbach niereprezentatywnych, jakimi są najczęściej ich niestacjonarni (studiujący nauczyciele) - studenci pedagogiki (np. badania H. Kwiatkowskiej czy A. Nalaskowskiego). Ks. J. Zowczak osadza wyniki swoich badań na tle bardzo dobrze dobranych do analizy komparatystycznej raportów z badań naukowców, których wspólnym mianownikiem jest czas zachodzących w polskim systemie oświatowym przemian i skupienie się na różnych wymiarach pełnienia roli społeczno-zawodowej przez nauczycieli. 
Można oczywiście, przy tak szerokim syntetyczno-analitycznym studium nauczycielskiej profesji polemizować z niektórymi tezami jego autora czy zwrócić uwagę na niektóre słabości, jakie w tym dziele się znalazły, nie przesądzając jednak na jego niekorzyść. Raczej traktuję je jako okazję do kontynuowania dialogu naukowego i zachętę do dalszych penetracji badawczych. Nie ulega jednak wątpliwości, że zależało mu na tym, aby wykorzystać w swoich badaniach myśli humanistycznej nad etosem nauczyciela możliwie jak najwięcej źródeł. Nie mogę się jedynie zgodzić z przywołanymi we „Wprowadzeniu” tezami, że po upadku systemu socjalistycznego nasze społeczeństwo stało się znacznie silniej niż w PRL społeczeństwem „naśladowczym” czy „mimetycznym” w stosunku do społeczeństwa z zachodniego kręgu cywilizacyjnego (teza M. Ziółkowskiego, s. 27) oraz że powstała w naszym kraju próżnia instytucjonalna, która spowodowała „długotrwałe błądzenie po bezdrożach barbarzyństwa” (s. 35). Być może można ją odnieść do systemu gospodarczego czy opieki społecznej, ale nie do systemu oświatowego ${ }^{12}$.

Edukacja państwowa w posocjalistycznej Polsce zapewniała dzięki stosownym rozporządzeniom MEN i nowelizacji Ustawy o systemie oświaty warunki dla wolnej od indoktrynacji realizacji przez uczniów treści kształcenia oraz dla „eksperymentowania” przez nauczycieli w zakresie kształcenia tak, by uczenie się uwzględniało potrzeby, zdolności i zainteresowania uczniów, zaś nauczyciele mieli zagwarantowane prawo do twórczego realizowania tego procesu. Polscy nauczyciele nie tylko nie okazali się bezradni wobec zaistniałej, a radykalnej zmiany, uwalniającej ich od centralistycznego sterowania procesem kształcenia i wychowania w duchu jedynie słusznej ideologii, ale znakomicie wykorzystali zwróconą im wolność w stanowieniu o jakości edukacji, tworząc programy, klasy i szkoły autorskie właśnie w sferze publicznej, zaś część środowisk rodzicielskich jeszcze przed „Okragłym Stołem" uruchomiło nowy ruch społecznej edukacji (powołanie szkół społecznych STO). Nauczyciele nie musieli też sięgać po wzory amerykańskie czy brytyjskie, choć jeśli miało to miejsce, to głównie w obszarze modernizacji metod i technik nauczania, gdyż mogli przywołać wciąż aktualne i wartościowe dla kształcenia do życia w społeczeństwie wolnym, pluralistycznym najlepsze dokonania myśli pedagogicznej okresu II RP. Warto tu zwrócić uwagę, że kiedy minister edukacji M. Handke przekonywał do ustrojowej reformy szkolnictwa w polskim Parlamencie, to posługiwał się retoryką i źródłami pedagogicznymi właśnie z okresu tzw. reform jędrzejowskich.

12 B. Śliwerski, Problemy współczesnej edukacji. Dekonstrukcja polityki oświatowej III RP, Warszawa 2009. 
Nie można nie dostrzec faktu, że w okresie PRL, a więc totalitaryzmu sowieckiego (podobnie jak w okresie totalitaryzmu hitlerowskiego), istniał silny ruch polskiej, niezależnej edukacji i niezależnych ruchów wychowania narodowego, chrześcijańskiego, który wykształcił liderów dla edukacji w nowych warunkach politycznych, a wyłonionych zresztą bardzo szybko po odzyskaniu przez nasz kraj pełnej suwerenności politycznej. Tak więc zabrakło mi w niniejszej publikacji niezwykle ważnego nurtu podtrzymywania etosu wychowawcy, nauczyciela polskiego w drugim nurcie życia naszego społeczeństwa i jego współczesnych dziejów. A zatem nie przywoływałbym w analizach uzasadnień normatywnych dla czasów transformacji poglądów autorów, którzy byli ideologami socjalistycznej pedagogiki, jak np. S. Krawcewicz, B. Bromberek, H. Muszyński, Z. Kosyrz, gdyż ich publikacje i wyniki badań z czasem transformacji nie miały nic wspólnego. Przydałby się też w doborze współczesnej literatury pedeutologicznej większy krytycyzm, by nie przywoływać rozpraw, które wprawdzie podejmują tę problematykę, ale obciążone są rażącymi błędami merytorycznymi i metodologicznymi (np. K. Polak, H. Cudak).

Upublicznienie na początku lat 80. opozycyjnej wizji Samorządnej Rzeczypospolitej zaowocowało $\mathrm{w}$ środowisku oświatowym między innymi ideą tworzenia zawodowego samorządu nauczycieli, upatrując w nim szansę na wewnętrzną odnowę etyczną tego środowiska i przełamanie monopolu państwa w zakresie inicjatyw reformatorskich czy totalitarnych, centralistycznych form sprawowania władzy. Myślenie samorządowe, choć jakże ważne u podstaw głębokiej transformacji ustrojowej państwa, to jednak w tamtych latach nie miało szans na urzeczywistnienie w praktyce, gdyż społeczny ruch odnowy NSZZ „Solidarność” musiał jako pierwszy zaistnieć w ówczesnych realiach Polski, przygotowując przedpole do emancypacyjnych dążeń różnych grup pracowniczych, w tym i nauczycieli.

Ks. J. Zowczak powinien zatem odnotować w swojej dysertacji niezwykle istotny dla kształtowania etosu nauczycielskiego proces, który w wyniku tworzenia niezależnego, samorządnego związku zawodowego "Solidarność” w szkołach i strukturach administracji oświatowej przesłonił istotę pełnej autonomii środowiska nauczycielskiego, ale także uniemożliwił przyjęcie przez to środowisko Kodeksu Etyki Nauczycielskiej. To związki zawodowe stają się głównym czynnikiem oporu przed samonaprawą środowiska nauczycielskiego w kategoriach egzekwowania w nim i przez nie etosu zawodowego. Nie dostrzega się, że wyzwoleniu związkowemu, pracowniczemu może towarzyszyć równolegle rzeczywista transformacja stosunków społecznych w relacjach całej społeczności nauczycieli tak do władz oświatowych, jak i aparatu państwowego. 
Stwierdzenie zatem przez tego autora, że Zofia Chomczyk jest autorką projektu powyższego Kodeksu, jest wyrwane ze znacznie szerszego i ważniejszego dla niego, jak i dla dalszych analiz oraz badań tej profesji kontekstu, sugerując zarazem fakt jego obowiązywania. Tymczasem pani ta była pomysłodawczynią utworzenia w Polsce samorządu zawodowego nauczycieli, a tym samym ich suwerennego wyzwolenia się ze stanu zniewolenia i przezwyciężania niekorzystnych barier w realizacji profesjonalnych i etycznych zadań, którego narzędziem miał być także Kodeks Etyczny Nauczycieli. Prace studialne nad etosem zawodowym stanu nauczycielskiego rozpoczęła już w 1974 r., proponując tworzenie izb nauczycielskich. Idea pełnej samorządności nauczycieli spotkała się z konkretną inicjatywą projektodawczą dopiero w latach 1991-1992, kiedy to przy Krajowej Sekcji Oświaty NSZZ „Solidarność” powołano Krajowy Zespół do spraw Izb Nauczycielskich. W roku 1991 Z. Chomczyk zorganizowała dwa kongresy tego zespołu, w trakcie których przeanalizowano wyniki ogólnopolskich badań nad potrzebą opracowania kodeksu etycznego nauczycieli i tworzenia samorządu zawodowego tej grupy zawodowej.

Efektem prac powyższego zespołu było opracowanie projektu Ustawy o samorządzie nauczycieli, który opiniowany był także przez Biuro Prawne Kancelarii Prezydenta RP L. Wałęsy. Niestety, usytuowanie tego zespołu w strukturach związkowych doprowadziło do jego likwidacji w dn. 27.11.1992 r., kiedy to działacze związkowi odczytali kreowane w projekcie zadania jako zagrażające bytowi i realnym wpływom na środowisko ich organizacji pracowniczej. Od tej pory zespół ten mógł już pracować jedynie poza strukturami NSZZ „Solidarność”, organizując na Uniwersytecie Warszawskim jeszcze w listopadzie 1993 r. III Krajowy Kongres na temat etyki nauczycielskiej. Zeszła jednak na plan dalszy praca nad zainteresowaniem pedagogów idea, potrzebą czy wartością tworzenia samorządów nauczycielskich. Ponownie powróciła ona do publicznej debaty w marcu 1997 r., kiedy to z inicjatywy Zespołu d/s Samorządności przy Fundacji Instytut Lecha Wałęsy zorganizowane zostało ogólnopolskie seminarium w Łodzi, mające na celu przygotowanie projektu Ustawy o Samorządzie Zawodowym Nauczycieli dla Akcji Wyborczej „Solidarność”. Brałem udział w pracach tego gremium, wiem zatem, z jak wielkim oporem spotkały się jego inicjatywy właśnie w środowisku związkowym. To ono zablokowało nie tylko starania o powołanie samorządu zawodowego, ale i o wykluczenie z debaty publicznej i z projektów zmian prawnych Kodeksu Etyki Nauczycielskiej.

Powołanie zawodowego samorządu nauczycielskiego mogłoby, z racji immanentnie tkwiących $\mathrm{w}$ nim zasad samoregulacji etyczno-profesjonalnych, przeciwstawiać się szeroko pojmowanej toksyczności praktyki oświatowej. Zaangażowanie się izb nauczycielskich na rzecz etyki, a więc i wolno- 
ści jako jej podstawy, miało otwierać nowy horyzont aktywności zawodowej i strącić politykę z piedestału. Nie może bowiem istnieć etyka nauczycieli tam, gdzie zakwestionowana jest ich wolność. „Człowiek staje się podmiotem etyki dopiero wtedy, gdy uświadamia sobie, że jest wolny i gdy wybiera swą wolność jako zasadę działania"13. Środowisko nauczycielskie w trosce o swoją podmiotowość i odpowiedzialne sprawstwo pedagogiczne musiałoby się przeciwstawiać toksyczności oświaty i pseudopedagogów, a samo tego nie chce. Wpisanie zatem przez ks. J. Zowczaka do hipotezy V stwierdzenia, że „Kodeks etyki nauczycielskiej nie jest decydującym czynnikiem identyfikacji zawodowej z racji braku znajomości jego treści przez samych nauczycieli” (s. 72) jest nieuprawnione, gdyż w III RP nie został przyjęty i usankcjonowany żaden Kodeks etyki nauczycielskiej ${ }^{14}$.

„Nauczycielstwo to już sama z siebie etyka i moralność, gdyż bez etyki i moralności nie ma w tym zawodzie nauczycielstwa, a co najwyżej techno-pragmatycznie odrabiane najemstwo" - tak pisała na początku polskiej transformacji ustrojowej wybitna pedeutolog Henryka Kwiatkowska ${ }^{15}$. Moralność pozbawiona jest właściwej sobie sankcji, gdyż jej istotą jest bezinteresowność. Moralny nauczyciel to taki, który postępuje zgodnie z normami moralnymi nie ze względu na spodziewane korzyści (nagrody) lub z obawy przed karą (wynikającą z kodeksu), ale dlatego, gdyż bycie moralnym jest cenne samo w sobie (jest wartością autoteliczną). Nauczyciel, który nie szanuje norm etyki ogólnej jest osobą niemoralną, w związku z czym powinien podlegać ocenie opinii publicznej i albo dostosować się do obowiązujących w społeczeństwie zasad, albo zrezygnować z wykonywania tego zawodu (z własnej woli lub w wyniku postępowania administracyjnego).

W „Preambule” do wspomnianego powyżej Kodeksu Etyki Nauczycielskiej stwierdza się już w pierwszym zdaniu: „Kodeks Etyki Nauczycielskiej jest wezwaniem do wszystkich nauczycieli, aby w życiu i pracy zawodowej kierowali się zasadami moralnymi, prawdą i dobrem" ${ }^{16}$. Z jednej strony uważa się, że nauczyciele nie są żadną wyjątkową grupą profesjonalistów, toteż powinni podlegać tym samym prawom natury i porządku społecznego, z drugiej jednak podkreśla się w debacie publicznej, że ze względu na uzyskanie przez nich statusu funkcjonariuszy publicznych powinni oni być oceniani w sposób szczególny w porównaniu z przedstawicielami innych profesji. Nauczyciel może bowiem nadużyć swojej władzy pedagogicznej

13 J. Tischner, Etyka solidarności oraz Homo Sovieticus, Kraków 1992, s. 143.

${ }^{14}$ Szerzej: B. Śliwerski, Jak zmieniać szkotę, Kraków 1998.

${ }^{15}$ H. Kwiatkowska, Etos zawodowy nauczyciela i jego przemiany, w: J. Nowak (red.), Przemiany zawodu nauczycielskiego, Wrocław, Warszawa, Kraków 1991, s. 201.

16 www.admzsg.edu.pl/zzyciaszkoly/wp-content/uploads/2007/06/kodeks-etykinauczycielskiej.pdf 
wobec wychowanków czy innych osób związanych z wykonywaną przez niego pracą. Prawdopodobnie mające miejsce przypadki trafiania do pracy w oświacie osób o nie najwyższym poziomie moralnym sprawia, że poszukuje się narzędzia do ich rozpoznawania, oceniania i wykluczania $\mathrm{z}$ tego obszaru wpływów społecznych.

Liczne badania codzienności życia w szkołach wykazują, że ma w nich miejsce nie tylko zabroniona przemoc fizyczna nauczycieli wobec uczniów, ale - co gorsza, bo trudniejsza do wykrycia i udowodnienia - przemoc psychiczna, jaką oni stosują wobec swoich podopiecznych w postaci: obelg, pomówień, szantażu, gróźb, etykietowania, bagatelizowania, publicznego obnażania, agresji słownej itp. Jeśli zatem pojawiają się co jakiś czas próby przyjęcia kodeksu etycznego nauczycieli, to prawdopodobnie głównie ze względu na przeświadczenie o tym, że część przedstawicieli tej grupy zawodowej cechuje słabość moralna, a zastosowany przez prawo pozytywne wobec nich przymus w postaci sankcji, jakie będą określone w kodeksie, może częściowo przynajmniej zminimalizować przemoc z jego strony wobec innych i przyczynić się do upowszechnienia właściwych wzorów postępowania moralnego.

Usankcjonowanie zatem w kodeksie etycznym określonych zachowań jako godnych tego zawodu oraz wskazanie na te, które jemu zaprzeczaja, powinno sprzyjać postawom moralnym pedagogów wobec innych osób. Może przy tym wzmacniać przestrzeganie prawa i regulacji służbowych, zobowiązując nauczycieli do odpowiedzialnej służby pedagogicznej oraz nobilitując ich wrażliwość moralną w sytuacjach zawodowych. Kodeks etyczny nauczycieli promuje przy tym cnoty, które wpisują w ich działania wartości moralne, których wdrażanie $\mathrm{w}$ życie nie może być strzeżone przez żadne sankcje karne. Tym samym efektem ubocznym miałoby być przywrócenie właściwego miejsca pojęciu honoru pedagogicznego czy godności nauczycielskiej.

Pojawiają się jednak wątpliwości, czy możliwe jest stworzenie kodeksu, który z jednej strony nie byłby ułomny i niekompletny, z drugiej zaś mógłby rozstrzygać, co należy czynić w różnych sytuacjach oświatowych i w życiu prywatnym? Istnieje także obawa, by skodyfikowane w takim dokumencie wartości etyczne nie zostały wykorzystane do celów pozamoralnych, jak np. jako środki do wymuszania uległości pedagogów wobec określonej ideologii czy polityki władz oświatowych. Kodeksy czy akty prawne noszą przecież znamiona niedoskonałości, toteż poszanowanie norm moralnych w relacjach z uczniami przez ich nauczycieli nie nastapi od razu ani dzięki etycznym apelom pedagogów, władz czy opinii publicznej, ani też dzięki konstytuowaniu nowych stosunków międzypodmiotowych w szkole na bazie ich regulacji prawnych. Nienaruszalności przez nauczycieli norm moral- 
nych wobec kogokolwiek nie sprosta samo włączenie do systemu oświaty publicznej mechanizmów ochrony prawnej, gdyż ta jest dziełem ludzi dorosłych, którzy nie do końca są przekonani o konieczności dwustronności obowiązywania tych norm.

Czy rzeczywiście proponowanie elementarnych dyrektyw moralnych, które miałyby być świadectwem odrębności zawodowej i etycznej tej grupy osób ma sens? Dziennikarze już eksponują w krytyce tego projektu to, że w wyniku jego powstania nastąpi zerwanie z zawodową lojalnością, gdyż nauczyciele będą zobowiązani do donoszenia na kolegów. Jak donosi „Gazeta Prawna":

Wśród propozycji tam zawartych są też takie, które już teraz budzą kontrowersje. Jedną z nich jest zapis, że pedagog powinien wystrzegać się zachowań, których celem jest ukrywanie niekompetencji kolegów i ich zawodowej nieudolności. - Przepis ten sugeruje, że w szkole pracują niekompetentni nauczyciele, na których trzeba donosić do dyrektora czy gminy - mówi Joanna Berdzik, prezes Ogólnopolskiego Stowarzyszenia Kadry Kierowniczej Oświaty. Jej zdaniem kodeks powinien raczej nakładać na nauczycieli obowiązek, aby pomagali innym, którzy wykazują się np. nieudolnością w swojej pracy. Takiego zapisu broni Sławomir Broniarz, prezes Związku Nauczycielstwa Polskiego (ZNP). Przekonuje, że kodeks ma jedynie pomóc nauczycielowi stać się asertywnym w stosunku do innego nauczyciela, któremu trzeba powiedzieć, że np. źle prowadzi zajęcia ${ }^{17}$.

Warto też zajrzeć na stronę Zespołu Szkół - Szkoła Podstawowa i Gimnazjum w Jaszczwi, gdzie został udostępniony Kodeks etyczny nauczycieli ${ }^{18}$. Nauczyciele z tego zespołu nie czekali na stworzony przez związkowców czy urzędników oświatowych kodeks, ale opracowali własny. Pedagodzy z tej placówki powołali specjalną Komisję Etyczną, która rozpatruje skargi na zaistniałe w tej szkole nieetyczne wydarzenie $\mathrm{z}$ udziałem nauczyciela i podejmuje konkretne rozwiązanie tej kwestii. Jak się okazuje, w powyższej sprawie mogą wnioskować pracownicy szkoły, rodzice oraz uczniowie, wypełniając formularz dostępny w sekretariacie szkoły i składając go do tej Komisji.

Komisja Etyczna składa się z trzech osób wybranych spośród nauczycieli w tajnym głosowaniu Rady Pedagogicznej oraz z przedstawiciela Rady Rodziców.

17 www.dziennik.pl/wydarzenia/article513632/Nauczyciele_beda_donosic_na_kolegow.html

18 www.zsjaszczew.w.interia.pl/kodeks.doc 
Głosowanie odbywa się na sierpniowym posiedzeniu Rady Pedagogicznej inaugurującej nowy rok szkolny, natomiast wybór przedstawiciela Rady Rodziców na wrześniowym spotkaniu z rodzicami. Kadencja Komisji Etycznej trwa jeden rok szkolny, a jej skład jest wywieszony w pokoju nauczycielskim.

Postępowanie w razie naruszenia zasad kodeksu etycznego:

1. Rozmowa z Komisją Etyczną w celu wyjaśnienia zajścia i dojścia do wspólnego rozwiązania (porozumienie ustne).

2. Ponowna rozmowa z komisją zakończona notatką służbową.

3. Rozmowa z komisją kończąca się podpisaniem kontraktu.

4. Rozmowa z dyrektorem szkoły.

5. Przedstawienie problemu na posiedzeniu Rady Pedagogicznej ${ }^{19}$.

Kodeks etyczny tej profesji sam w sobie jeszcze nie wystarczy. Muszą być wprowadzone procedury diagnostyczne i umożliwiające ofiarom nieetycznych postaw nauczycieli dochodzenie z tego tytułu określonych roszczeń. Inna kwestia to taka, czy są one właściwe i wystarczające. Nie znamy treści tworzonego w 2009 r. kolejnego projektu Kodeksu Etyki Nauczycielskiej, a jedynie jedno z zapisanych w nim zobowiązań. Warto zatem skorzystać z wyników badań i analiz teoretycznych ks. Jana Zowczaka, by dialog w edukacji opierać na zgodnych z Ustawą o systemie oświaty chrześcijańskich wartościach etycznych.

\section{Revd Jan Zowczak's Sociopedeutological Research in the Context of Successive Stages of Teachers' Code of Ethics Development (Summary)}

The author explores the issues in Revd Jan Zowczak's sociopedeutological research in the context of the 1980s debate regarding teachers' professional ethics and the necessity to elevate the moral condition of the teaching profession through adoption of the teachers' code of ethics.

19 Tamże. 